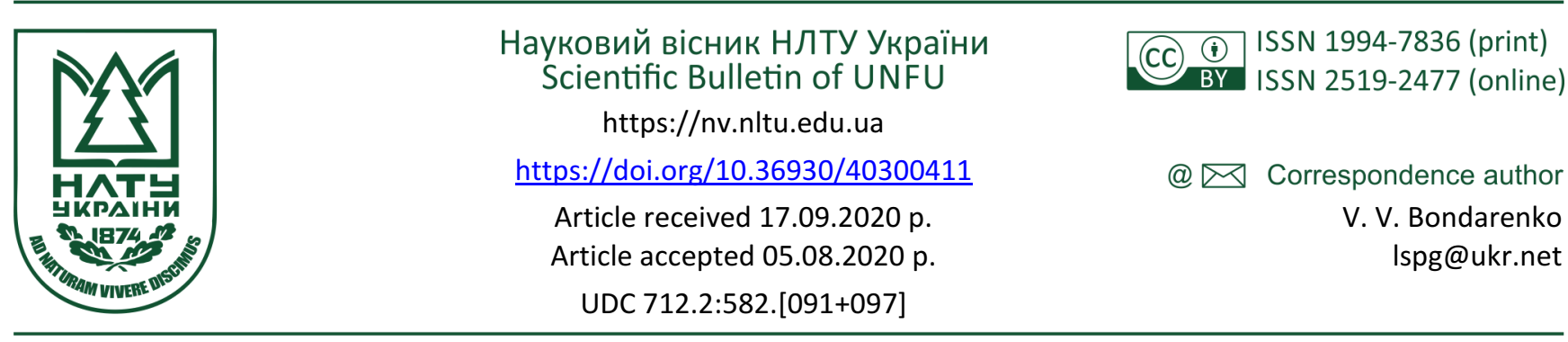

О. І. Лялін ${ }^{1}$ В. В. Бондаренко ${ }^{1}$, С. І. Мусієнко ${ }^{1}$, О. М. Тарнопільська ${ }^{1}$, Л. І. Ткач2, А. В. Бабенко

${ }^{l}$ Український ордена "Знак пошани" науково-дослідний інститут лісового господарства і агролісомеліорації ім. Г. М. Висоиького, м. Харків, Україна

${ }^{2}$ Харківський національний університет міського господарства ім. О. М. Бекетова, м. Харків, Україна

\title{
СУЧАСНИЙ СТАН НАСАДЖЕНЬ ДЕНДРОПАРКУ "ВОЛОДИМИРІВСЬКИЙ" ДП "ГУТЯНСЬКЕ ЛІСОВЕ ГОСПОДАРСТВО" ТА ПЕРСПЕКТИВИ ЙОГО РОЗВИТКУ
}

Визначено сучасний стан, виявлено назрілі проблеми та встановлено пріоритети подальшого розвитку дендропарку "Володимирівський" державного підприємства "Гутянське лісове господарство". Проведено збір даних і впорядкування відомостей про досліджувану дендрологічну частину парку. На підставі аналізу дослідних даних визначено найважливіші цінності дендрологічної частини: природні, соціально-економічні, культурні, рекреаційні, естетичні, еколого-освітні; окреслено пріоритети щодо їх збереження, охорони та відтворення. Проаналізовано фактори впливу на цінності та функціональність дендрологічної частини лісового фонду із ранжуванням проблем. Виділено 21 просторовий складовий елемент. Територія дендропарку поділена на дві частини - заповідну (лісову прогулянкову) зону та зону регульованої рекреації, що умовно розділені модриновою алею, яка бере свій початок від центральної брами в північній частині парку і закінчується біля бесідки для відпочинку відвідувачів у південній частині. Підтверджено, що особливої природної цінності та неповторності парк набуває завдяки 12 дубам-велетням 100-річного віку, із середнім діаметром 56 см і середньою висотою 23,5 м, що утворили куртину площею 0,21 га. Проаналізовано стан панівної за площею породи Pinus sylvestris L. і встановлено, що насадження цієї рослини штучного походження 50-60-річного віку із чагарниковим підліском займає площу 0,28 га, а природні 8-12-річного віку - 3,35 га, що разом становить 3,63 га, або 51 \% від площі дендропарку. Відзначено, що на площі 1,1 га сосна звичайна зростає із природним поновленням Betula pendula Roth., Populus tremula L., Acer platanoides, Acer negundo. 3'ясовано, що серед зелених насаджень парку переважають деревостани II класу віку, а переважаючою повнотою насаджень парку $\epsilon$ повнота 1,0. За результатами оцінювання сучасного стану подано рекомендації щодо розвитку території дендропарку.

Ключові слова: дендропарк; дендрологічна частина лісового фонду; видовий склад; оцінка стану.

\section{Вступ}

Дендрологічна частина лісового фонду Володимирівського лісництва ДП "Гутянське лісове господарство" належить до категорії "інші ліси", що мають важливе значення для захисту навколишнього природного середовища". Зважаючи на викладене вище виникає необхідність створення Дендрологічного ландшафтного парку. На території лісництва (у кварталі 32) було виділено ділянку для створення відповідного дендропарку ландшафтного типу "Володимирівський", закладку якого розпочато за ініціативи керівництва ДП "Гутянське
ЛГ" та підтримки Харківського обласного управління лісового та мисливського господарства 19 квітня 2003 р. На сьогодні загальна його площа становить близько 7,0 га.

Об'єкт дослідження - територія дендропарку "Володимирівський" ДП "Гутянське лісове господарство".

Предмет дослідження - обгрунтування заходів 3 покращення дендропарку "Володимирівський" ДП "Гутянське лісове господарство".

Мета дослідження: оцінити сучасний стан території дендропарку "Володимирівський" ДП "Гутянське лісове господарство" для обгрунтування заходів з його покращення.

Інформація про авторів:

Лялін Олександр Іванович, канд. с.-г. наук, доцент, лабораторія моніторингу і сертифікації лісів. Email: o_lyalin@ukr.net; https://orcid.org/0000-0002-8921-3605

Бондаренко Віра Володимирівна, мол. нак. співробіник, лабораторія лісівництва. Email: Ispg@ukr.net; https://orcid.org/0000-0001-8187-5519

Мусієнко Сергій Іванович, канд. с.-г. наук, ст. наук. співробітник, лабораторія лісівництва. Email: musienkosergij_les@ukr.net; https://orcid.org/0000-0002-6581-2670

Тарнопільська Оксана Михайлівна, канд. с.-г. наук, ст. наук. співробітник, лабораторія лісівництва. Email: tarnoks@ukr.net; https://orcid.org/0000-0002-4810-8892

Ткач Людмила Іванівна, канд. с.-г. наук, доцент, кафедра інженерної екології міст. Email: tkachly@i.ua; https://orcid.org/0000-0002-7790-5911

Бабенко Анна Володимирівна, магістрант, кафедра інженерної екології міст. Email: anna.babenko.1999@mail.ru; https://orcid.org/0000-0001-8187-5519

Цитування за ДСтУ: Лялін О. І., Бондаренко В. В., Мусієнко С. І., Тарнопільська О. М., Ткач Л. І., Бабенко А. В. Сучасний стан насаджень дендропарку "Володимирівський" ДП "Гутянське лісове господарство" та перспективи його розвитку. Науковий вісник НЛтУ України. 2020, т. 30, № 4. С. 62-66.

Citation APA: Lialin, O. I., Bondarenko, V. V., Musienko, S. I., Tarnopilska, O. M., Tkach, L. I., \& Babenko, A. V. (2020). The current state of the plantations of Volodymyrivsky Arboretum of Gutyanske forestry enterprise and prospects of its development. Scientific Bulletin of UNFU, 30(4), 62-66. https://doi.org/10.36930/40300411 
Для досягнення зазначеної мети потрібно виконати такі основні завдання дослідження: визначити сучасний стан, виявити назрілі проблеми та встановити пріоритети подальшого розвитку дендропарку "Володимирівський".

Наукова новизна отриманих результатів дослідження полягає в розробленні проектної пропозиції з архітектурно-ландшафтної організації заданого об'єкта озеленення і зелених насаджень.

Практична значущість результатів дослідження: отримані результати роботи дають можливість практичної реалізації проекту озеленення території дендропарку "Володимирівський".

Аналіз останніх досліджень та публікацій. Парк - самостійний архітектурно-організаційний комплекс площею понад 2 га, який виконує санітарно-гігієнічні функції та призначений для короткочасного відпочинку населення.

Дендрологічний парк (дендропарк, дендрарій, від грец. Dendron - дерево) або арборетум (від лат. arbor) територія, на якій на відкритому грунті культивуються деревні рослини. Парк з колекцією різних порід дерев [3].

Насадження в дендропарку, зазвичай у стилі ландшафтного парку, можуть бути самостійними або входити до складу ботанічного саду. Розміщення рослин здійснюється за систематичною, географічною, екологічною, декоративною або іншими ознаками.

Територія дендрологічних парків позначається на місцевості межовими охоронними знаками. Ми знаємо, що найкращий художник, скульптор і архітектор - це природа. Вона створює неймовірної краси ландшафти, фігури, форми і кольори. А ми можемо, оглядаючись на ці шедеври, створювати оазиси природи у себе вдома. I часто серед великих кам'яних міст вони - наче острівки гармонії та спокою, наче куточки земного раю, куди хочеться повертатись щоразу, аби почерпнути душевного спокою.

Дендрологічні парки України - зони культивування різних видів рослин, часто рідкісних і екзотичних, поряд 3 якими створюють красиві декоративні споруди, скульптури, штучні водойми, часом навіть імітуються шедеври світової архітектури. Аби перед нами постали такі парки, які докладалися десятиліттями, або й століттями важкої праці. Та головне - сюди вкладена велика любов до природи і мистецький ентузіазм садівників, лісників, скульпторів.

У нашій країні $є$ багато дендрологічних парків. Деякі з них мають 200-річну історію і належать до найстаріших в Європі, інші - засновані в останні десятиліття і тільки доповнюються та розбудовуються. Та більшість із них потребують більшої уваги до себе, ніж мають зараз. Відновлення, реконструкції, чи просто бережливого ставлення людей, чекають десятки заповідних парків, красу яких часто так нерозумно ми експлуатуємо [8].

Відповідно до Закону "Про природно-заповідний фонд України" (ст. 33) дендрологічні парки створюють 3 метою збереження і вивчення у спеціально створених умовах різноманітних видів дерев і чагарників та їх композицій для найефективнішого наукового, культурного, рекреаційного та іншого використання [9].

Дендрологічні парки загальнодержавного значення $\epsilon$ науково-дослідними природоохоронними установами. Дендрологічним паркам місцевого значення у встановленому порядку може бути надано статус науково-дослідної установи.

Земельні ділянки з усіма природними ресурсами вилучаються 3 господарського використання і надаються дендрологічним паркам у порядку, встановленому цим Законом та іншими актами законодавства України.

Основні вимоги щодо режиму дендрологічних парків мають такий вигляд:

- На території дендрологічних парків забороняється діяльність, що не пов'язана з виконанням покладених на них завдань і загрожує збереженню дендрологічних колекцій.

- На території дендрологічних парків може бути проведено зонування відповідно до вимог чинного законодавства.

- Проект організації території дендрологічного парку розробляють спеціалізовані наукові та проектні установи і затверджується органом, у підпорядкуванні якого перебуває дендрологічний парк, за погодженням 3:

- центральним органом виконавчої влади в галузі охорони навколишнього природного середовища - щодо дендрологічних парків загальнодержавного значення;

- органами центрального органу виконавчої влади в галузі охорони навколишнього природного середовища на місцях, а на території Автономної Республіки Крим - органом виконавчої влади Автономної Республіки Крим з питань охорони навколишнього природного середовища - щодо дендрологічних парків місцевого значення [9].

Для вивчення сучасного стану парку виконано комплекс дослідницьких і вишукувальних робіт з визначення стану лісових, паркових насаджень, стану гідротехнічних споруд та прогулянкових доріг.

Історико-бібліографічні дослідження потрібні для проведення ретроспективного аналізу функціонування парку з визначенням історичного вигляду та напрямків використання окремих ділянок парку на різних етапах його розвитку. Вони полягають у вивченні картографічних і фотоматеріалів, встановленні відомостей про паркові будівлі, видовий склад насаджень, структуру ландшафтів та межі парку.

Матеріали та методи дослідження. Матеріалами для дослідження слугували письмові та картографічні матеріали, а також результати польових обстежень дендропарку. Дослідження проводили методом подеревної інвентаризації згідно з інструкцією 3 інвентаризації насаджень [4]. Категорію цінності об'єкта досліджень визначали за критеріями комплексної оцінки сучасного стану парків-пам'яток дендрологічної цінності [5]. Таксономічний склад визначали на основі аналізу результатів польових обстежень, який уточнювали із довідковими джерелами та міжнародним списком "Тhe Plant List" (The plant list). Розподіл за життєвими формами проводили за методикою I. Г. Сєрєбрякова [6], опис та визначення основних характеристик топіарних елементів - за методикою А. А. Дзиби [1].

Під час досліджень використовували технологію FieldMap [2]. Field-Map - це комплексна технологія для ефективного збирання даних у польових умовах і їх подальшого оброблення. Вона об'єднує програмне забезпечення та електронні вимірювальні прилади для картування i дендрометричних вимірювань. Field-Mар охоплює низку різних завдань, починаючи від вимірів окремих дерев, під час картування дослідних або інвентаризаційних площ, цілих лісових насаджень і аж до рівня ландшафтних одиниць. Field-Мар використовують у багатьох проектах у галузі лісової науки, лісовпорядкування, лісового господарства, картування ландшафтів та для інших робіт.

Ця технологія $€$ гнучким програмно-інструментальний засобом для збирання та управління польовими даними, яка легко адаптується до задач, визначених користувачем. Застосування Field-Мар під час виконання польових робіт дає змогу в єдиному технологічному процесі формувати в польовому комп'ютері атрибутив- 
ну та картографічну інформацію про лісові об'єкти, максимально автоматизувати процедури вимірів лісотаксаційних i інших показників у лісі, забезпечує контроль повноти та вірогідності інформації. Під час проведення вимірів 3 високою точністю визначаються площі та атрибутивні показники вимірюваних об'єктів, забезпечується контроль повноти й вірогідності інформації, формуються бази даних вимірів, відображаються об'єкти на електронній карті в комп'ютері безпосередньо в польових умовах [2].

В основу досліджень покладено статистичний і логічний аналізи інформаційних матеріалів; використовували лісівничо-таксаційні методи - для визначення таксаційних показників поодиноких дерев і біогруп (куртин) та обліку природного поновлення; математичностатистичні - під час оброблення результатів досліджень. Результати досліджень обробляли за допомогою електронних таблиць Microsoft Office Excel.

\section{Результати дослідження та їх обговорення}

Відповідно до наявних відомостей загальна площа дендропарку ландшафтного типу "Володимирівський" становить близько 7,0 га. Як і на момент створення, існує центральна алея, що поділяє територію на дві частини - заповідну (лісову прогулянкову) зону та зону регульованої рекреації, змінились тільки інтенсивність використання та рівень догляду за окремими ділянками парку (рис. 1).

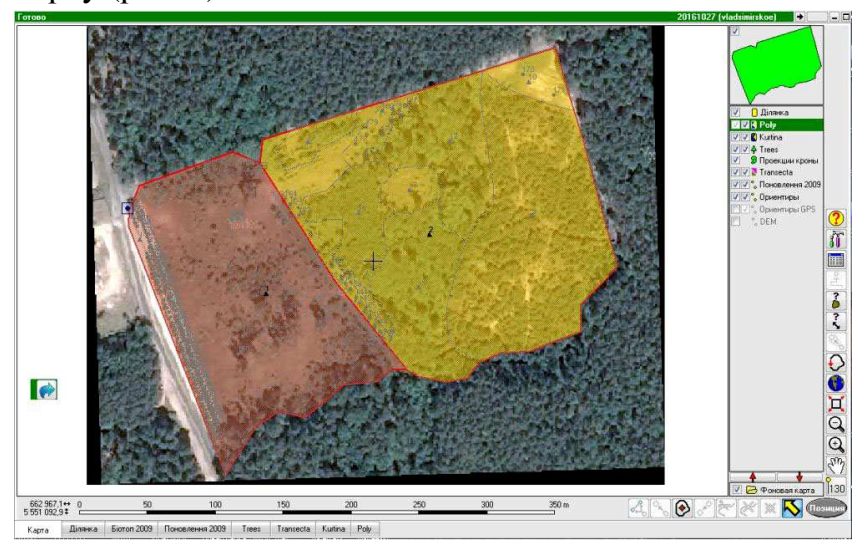

Рис. 1. Зонування території дендропарку "Володимирівський":

1) зона регульованої рекреації; 2) заповідна зона

Табл. 1. Баланс території дендропарку "Володимирівський"

\begin{tabular}{|l|c|c|}
\hline \multicolumn{1}{|c|}{ Складовий елемент } & Площа, га & Частка, \% \\
\hline Лісові масиви* & 3,54 & 54,01 \\
\hline Ландшафтні групи та солітери & 0,68 & 10,31 \\
\hline Алеї & 0,63 & 9,58 \\
\hline Поляни та галявини & 1,49 & 22,71 \\
\hline Прогулянкові дороги & 0,10 & 1,50 \\
\hline Водоймища & 0,12 & 1,86 \\
\hline Забудова & 0,003 & 0,05 \\
\hline Разом & $\mathbf{6 , 5 6}$ & $\mathbf{1 0 0}$ \\
\hline
\end{tabular}

Примітка: * насадження утворилися у природний спосіб.

Після вивчення історичних і картографічних матеріалів, а також здійсненого дослідження території ми встановили такий фактичний баланс його території (табл. 1). Як видно з даних цієї таблиці, загальна площа дендропарку становить 6,56 га, зокрема 4,83 га (або $73,6 \%$ ) вкриті деревною та чагарниковою рослинністю, а 1,73 га (або 26,4 \%) - не вкриті і використовуються як шляхи сполучення (стежки, дороги) та як зони для прогулянок та відпочинку.
На час проведення досліджень території ми виділили 21 просторовий складовий елемент території дендропарку (рис. 2). У центрі лісової зони розташований невеликий ставок із піщаними берегами, що має площу 0,12 га. Зони розподілені у центральній, підвищеній частині місцевості модриновою алеєю, що бере свій початок від центральної брами в північній частині парку і закінчується біля бесідки для відпочинку відвідувачів у південній частині.

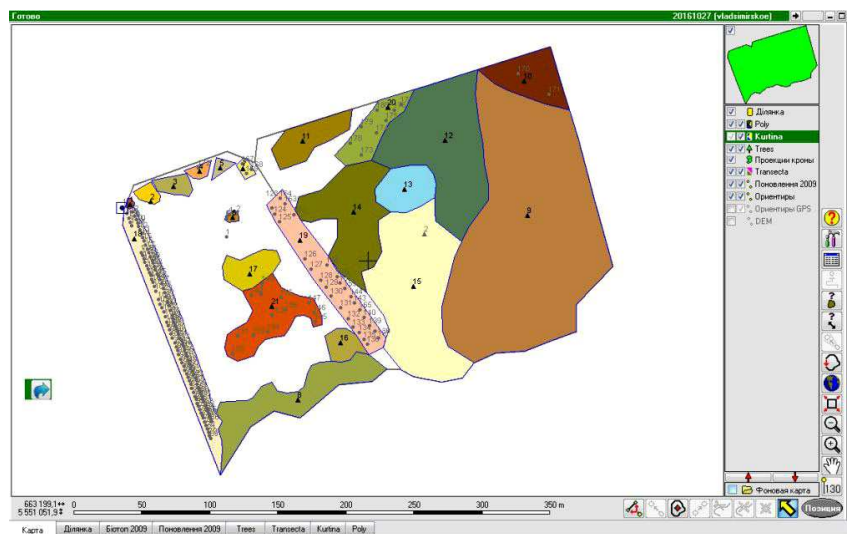

Рис. 2. Характеристика території дендропарку "Володимирівський" із виділенням його ландшафтних груп (куртин)

Тому ця алея, або короткопланова видова просіка, $\epsilon$ головною композиційною віссю паркового комплексу, вздовж якої, від входу в парк, відкривається вид як на поодинокі солітери 3 куртинами зони регульованої рекреації, так і на лісові насадження заповідної зони. У південній частині вона замикається бельведером (бесідкою), що оточена природно формованими насадженнями сосни звичайної. 3 утвореного тут майданчика для відпочинку відкривався вид як на згадані вище паркові зони, так і на пристигаюче насадження сосни звичайної, що межує $з$ дендропарком 3 півдня.

Листяні дерева в куртинах розташовані за принципом рівноваги та грунтової відповідності $з$ обох боків композиційної осі і гармонійно сприймалися серед дикорослих трав'яно-квітникових полян, на фоні заднього плану хвойного лісового масиву. Вздовж цієї осі, мережею серпантинних прогулянкових стежок, що серпантином підіймались по правому крутому берегу, можна було потрапити як у лісову прогулянкову зону, так і у дещо вільну від деревно-чагарникової рослинності зону регульованої рекреації.

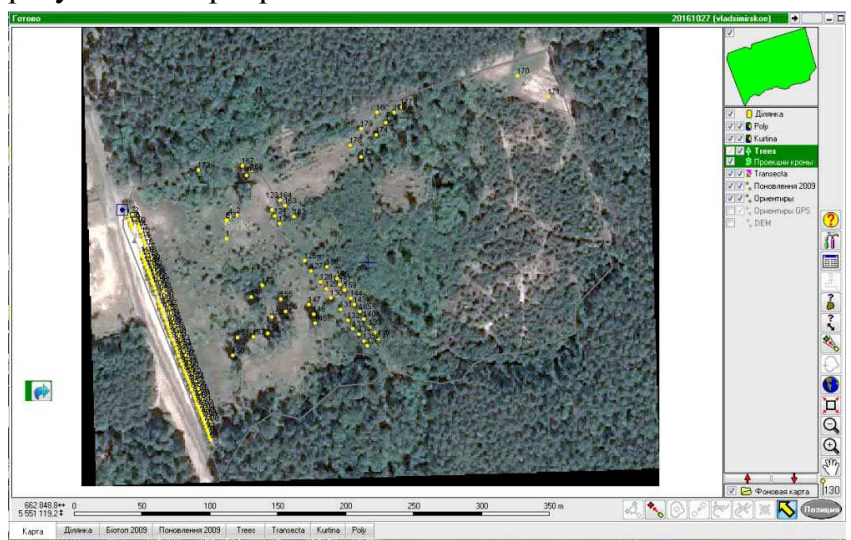

Рис. 3. Розташування дерев у ландшафтних групах на території дендропарку "Володимирівський"

Особливої природної цінності та неповторності парк набуває завдяки 12 дубам-велетням 100-річного віку, зі 
середнім діаметром 56 см і середньою висотою 23,5 м, що утворили куртину площею 0,21 га.

Панівною за площею породою у дендропарку "Володимирівський" є сосна звичайна (Pinus sylvestris L.). Ïї насадження штучного походження 50-60-річного віку із чагарниковим підліском займає площу 0,28 га, а природні насіннєві 8-12-річного віку - 3,35 га, що разом становить 3,63 га, або $51 \%$ від площі дендропарку. Хоча варто зазначити, що на 1,1 га 3 цієї площі сосна звичайна зростає разом із природним поновленням Betula pendula Roth., Populus tremula L., Acer platanoides, Acer negundo.

На рис. 3 зображено розташування дерев у ландшафтних групах по території дендропарку.

Ялина звичайна (Picea abies (L.) Karst) займає 0,28 га, або 4,3\% площі дендропарку і зростає у курти- ні № 18 алейного розміщення. Алея модрини тонколускатої (японської) (Larix kaempferi) (куртина № 19) розташована на площі у 0,23 га, або 3,5 \%, а алея туї західної (Thuja occidentalis L.) (куртина № 20) - 0,12 га.

Дуб звичайний (Quercus robur L.) представлений двома куртинами (№ 7 та 21) і займає площу 0,22 га, або 3,4 \% площі дендропарку; дуб червоний (Quercus rubra L.) (куртина № 11) - 0,12 га. Інші породи займають незначну площу або представлені поодинокими екземплярами.

У табл. 2 подано результати польових вимірів та їх обрахунків для куртин, що складалися як мінімум із 2 екземплярів і були створені у час закладання дендропарку, тобто впродовж 2003-2004 pр.

Табл. 2. Середні біометричні показники росту дерев та чагарників у ландшафтних групах дендропарку "Володимирівський"

\begin{tabular}{|c|c|c|c|c|c|c|c|c|c|c|c|c|c|c|}
\hline $\begin{array}{c}\text { № ландшафтної } \\
\text { групи (див. рис. 1) }\end{array}$ & \multicolumn{2}{|c|}{1} & & \multicolumn{2}{|c|}{ 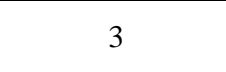 } & \multicolumn{2}{|c|}{5} & & \multicolumn{2}{|c|}{6} & \multicolumn{2}{|c|}{7} \\
\hline Видова назва & $\begin{array}{r}\text { Клен I } \\
\text { ла (Ace } \\
\text { nal }\end{array}$ & $\begin{array}{l}\text { інна- } \\
\text { r gin- } \\
\text { a) }\end{array}$ & $\begin{array}{r}\text { Сум } \\
\text { бильни } \\
\text { coria }\end{array}$ & $\begin{array}{l}x \text { ду- } \\
\text { 1 (Rhus } \\
\text { ia } \mathrm{L} \text {.) }\end{array}$ & $\begin{array}{r}\text { Клен го } \\
\text { тий (А } \\
\text { no }\end{array}$ & $\begin{array}{l}\text { гролис- } \\
\text { r plata- } \\
\text { es) }\end{array}$ & $\begin{array}{r}\text { Сум } \\
\text { бильни } \\
\text { coria }\end{array}$ & $\begin{array}{l}x \text { ду- } \\
\text { 1 (Rhus } \\
\text { ia } \mathrm{L} .)\end{array}$ & $\begin{array}{c}\text { Сосна } \\
\text { (Pinus } \\
\text { ana } \mathrm{I}\end{array}$ & $\begin{array}{l}\text { Банкса } \\
\text { banksi- } \\
\text { amb.) }\end{array}$ & $\begin{array}{r}\text { Сосна } \\
\text { това } \\
\text { stro }\end{array}$ & $\begin{array}{l}\text { вейму- } \\
\text { (Pinus } \\
\text { us L) }\end{array}$ & $\begin{array}{r}\text { Ду } \\
\text { чайн } \\
e r c \\
b u \\
\end{array}$ & $\begin{array}{l}\text { 3Ви- } \\
\text { Ій }(Q u- \\
\text { s ro- } \\
\text { L.) }\end{array}$ \\
\hline Назва показника & $\mathrm{D}, \mathrm{cm}$ & $\mathrm{H}, \mathrm{M}$ & $\mathrm{D}, \mathrm{cm}$ & $\mathrm{H}, \mathrm{M}$ & $\mathrm{D}, \mathrm{cm}$ & $\mathrm{H}, \mathrm{M}$ & $\mathrm{D}, \mathrm{cm}$ & $\mathrm{H}, \mathrm{M}$ & $\mathrm{D}, \mathrm{cm}$ & $\mathrm{H}, \mathrm{M}$ & $\mathrm{D}, \mathrm{cm}$ & $\mathrm{H}, \mathrm{M}$ & $\mathrm{D}, \mathrm{cm}$ & $\mathrm{H}, \mathrm{M}$ \\
\hline Середнє значення & 5,83 & 8,00 & 11,75 & 4,97 & 10,27 & 7,91 & 10,5 & 5,57 & 7,5 & 2,6 & 8,25 & 3,2 & 71,17 & 25,03 \\
\hline Стандартна похибка & 0,74 & 0,00 & 1,47 & 0,29 & 0,45 & 0,22 & 0,18 & 0,14 & 2,93 & 0,64 & 5,75 & 2 & 3,94 & 1,35 \\
\hline $\begin{array}{l}\text { Стандартне відхи- } \\
\text { лення }\end{array}$ & 1,27 & 0,00 & 3,60 & 0,71 & 1,87 & 0,93 & 0,45 & 0,35 & 5,07 & 1,11 & 8,13 & 2,83 & 6,83 & 2,34 \\
\hline Мінімальне значення & 5,00 & 8,00 & 7,50 & 4,40 & 6,00 & 6,70 & 10,00 & 5,20 & 2,00 & 1,40 & 2,50 & 1,20 & 65,00 & 23,30 \\
\hline $\begin{array}{l}\text { Максимальне зна- } \\
\text { чення }\end{array}$ & 7,30 & 8,00 & 17 & 6,3 & 13 & 9,5 & 11,00 & 6,20 & 12,00 & 3,60 & 14,00 & 5,20 & 78,50 & 27,70 \\
\hline Кількість вимірів & 3 & 3 & 6 & 6 & 17 & 17 & 6 & 6 & 3 & 3 & 2 & 2 & 3 & 3 \\
\hline $\begin{array}{l}\text { Рівень надійності } \\
(95,0 \%)\end{array}$ & 3,17 & 0,00 & 3,78 & 0,74 & 0,96 & 0,48 & 0,47 & 0,37 & 12,61 & 2,77 & 73,06 & 25,41 & 16,95 & 5,82 \\
\hline Збереженість, \% & 100,0 & & 100,0 & & 100,0 & & 100,0 & & 100,0 & & 100,0 & & 100,0 & \\
\hline
\end{tabular}
продовження табл. 2.

\begin{tabular}{|c|c|c|c|c|c|c|c|c|c|c|c|c|c|c|}
\hline $\begin{array}{c}\text { № ландшафтної групи } \\
\text { (див. рис. 1) }\end{array}$ & \multicolumn{2}{|c|}{10} & \multicolumn{2}{|c|}{12} & \multicolumn{2}{|c|}{12} & \multicolumn{2}{|c|}{18} & \multicolumn{2}{|c|}{19} & \multicolumn{2}{|c|}{20} & \multicolumn{2}{|c|}{21} \\
\hline Видова назва & \multicolumn{2}{|c|}{$\begin{array}{c}\text { Сосна } \\
\text { гірська }(P i- \\
\text { nus mиgo) }\end{array}$} & \multicolumn{2}{|c|}{$\begin{array}{c}\text { Дуб зви- } \\
\text { чайний (Quer- } \\
\text { cus robur L.) }\end{array}$} & \multicolumn{2}{|c|}{$\begin{array}{c}\text { Береза повисла } \\
\text { (Betula pendula } \\
\text { Roth.) }\end{array}$} & \multicolumn{2}{|c|}{$\begin{array}{c}\text { Ялина зви- } \\
\text { чайна (Picea } \\
\text { abies) }\end{array}$} & \multicolumn{2}{|c|}{\begin{tabular}{|c|} 
Модрина тон- \\
колуската \\
(Larix ka- \\
empferi \\
(Lam.) Carr.)
\end{tabular}} & \multicolumn{2}{|c|}{$\begin{array}{l}\text { Туя західна } \\
\text { (Thuja occi- } \\
\text { dentalis L.) }\end{array}$} & \multicolumn{2}{|c|}{$\begin{array}{c}\text { Дуб зви- } \\
\text { чайний (Qu- } \\
\text { ercus robur } \\
\text { L.) }\end{array}$} \\
\hline Назва показника & $\mathrm{D}, \mathrm{cm}$ & $\mathrm{H}, \mathrm{M}$ & $\mathrm{D}, \mathrm{cm}$ & $\mathrm{H}, \mathrm{M}$ & $\mathrm{D}, \mathrm{cm}$ & $\mathrm{H}, \mathrm{M}$ & $\mathrm{D}, \mathrm{cm}$ & $\mathrm{H}, \mathrm{M}$ & $\mathrm{D}, \mathrm{cm}$ & $\mathrm{H}, \mathrm{M}$ & $\mathrm{D}, \mathrm{cm}$ & $\mathrm{H}, \mathrm{M}$ & $\mathrm{D}, \mathrm{cm}$ & $\mathrm{H}, \mathrm{M}$ \\
\hline Середнє значення & 8,00 & 1,25 & 36,63 & 11,88 & 30,30 & 13,31 & 11,86 & 7,01 & 19,15 & 10,22 & 7,75 & 3,50 & 56,25 & 23,52 \\
\hline Стандартна похибка & 0,00 & 0,05 & 5,21 & 1,20 & 0,95 & 0,40 & 0,29 & 0,14 & 1,03 & 0,53 & 1,50 & 0,38 & 3,53 & 0,55 \\
\hline $\begin{array}{l}\text { Стандартне відхилен- } \\
\text { ня }\end{array}$ & 0,00 & 0,07 & 10,43 & 2,39 & 7,39 & 3,09 & 3,11 & 1,45 & 5,35 & 2,77 & 4,23 & 1,07 & 12,24 & 1,91 \\
\hline Мінімальне значення & 8,00 & 1,20 & 21,00 & 9,00 & 11,50 & 5,00 & 4,50 & 3,60 & 8,00 & 5,00 & 2,00 & 2,00 & 39,00 & 21,10 \\
\hline $\begin{array}{l}\text { Максимальне значен- } \\
\text { ня }\end{array}$ & 8,00 & 1,30 & 42,50 & 14,50 & 56,00 & 18,30 & 19,00 & 10,50 & 31,00 & 15,90 & 14,00 & 5,00 & 85,00 & 27,20 \\
\hline Кількість вимірів & 2 & 2 & 4 & 4 & 61 & 01 & 115 & 115 & 27 & 27 & 8 & 8 & 12 & 12 \\
\hline $\begin{array}{l}\text { Рівень надійності } \\
(95,0 \%)\end{array}$ & 0,00 & 0,64 & 16,59 & 3,81 & 1,89 & 0,79 & 0,58 & 0,27 & 2,12 & 1,10 & 3,54 & 0,89 & 7,78 & 1,22 \\
\hline Збереженість, \% & 6,67 & & $-*$ & & $-*$ & & 91,27 & & 56,30 & & 40,00 & & 100,0 & \\
\hline
\end{tabular}

Примітка: * не розраховували з причини відсутності даних про кількість висаджених екземплярів.

Варто додати характеристики ще декількох об'єктів. Насамперед це куртина № 4, де зростає груша маслинколиста (Pyrus elacagnifolia), що має певні характеристики займаної території, але представлена тільки одним екземпляром заввишки 6,8 м та має діаметр 6,5 см.

Окрім цього, між 3 та 5 куртинами зростає акація біла (Robinia pseudoacacia) у кількості 3 одиниць, $(d=8,0 ; 8,5$ та 6,0 см $h=10,7 ; 11,0$ та 9,4 м). Між ними росте один кущ бузини чорної (Sambucus nigra) 3 $h=2,2$ м. По межі дендропарку 3 дорогою куртини су- маха дубильного (Rhus coriaria L.) відмежовані живоплотом з бирючини звичайної (Ligustrum vulgare), висотою 1,5 м, довжиною 6 м (2 куртин $a$ ) та 30 м (4 куртина). Окремо варто зазначити куртину 11, що представлена 175 екземплярами дуба червоного (Quercus rub$r a \mathrm{~L}$.) iз $H=6$ м та $D=7,5$ см. Це єдина ландшафтна група дендропарку, що створена чистим масивом з 9 рядів і росте за I $\mathrm{I}^{\mathrm{a}}$ бонітетом.

Обговорення результатів дослідження. Варто зазначити, що серед зелених насаджень парку переважа- 
ють деревостани II класу віку, оскільки дендропарк створено у 2003 р. Їх площа становить 4,35 га, або $90 \%$ вкритої зеленими насадженнями площі. Інші 0,5 га, або $10 \%$ займають дерева дуба звичайного 11-12 класу віку у куртинах № 7 та 21 і сосни звичайної 6-7 класу віку у куртині № 8 .

Переважаючою повнотою насаджень парку є повнота 1,0. Насадження 3 цією повнотою займають площу 3,9 га, або 79 \% лісової площі. Площа штучно створених насаджень 3 повнотою нижче 0,3 у дендропарку становить 0,016 га, це куртина № 10 сосни гірської, де на сьогодні зростає тільки 2 екземпляри. Викликає занепокоєння зрідження алеї туї західної до повноти 0,30,4 , площа якої 0,12 га.

Хоча і вік насаджень у дендропарку переважно незначний, але більшість насаджень зростає за досить високими класами бонітету. Так, насадження I класу бонітету і вище займають площу 55,6 \%, насадження II класу бонітету і нижче - 41,6\%. Середній клас бонітету насаджень парку - 1,5.

\section{Висновки}

1. Унаслідок дослідження та аналізу території дендропарку "Володимирівський" ДП "Гутянське лісове господарство" визначено, що створені куртини деревних порід здебільшого зберегли свої контури.

2. Встановлено, що за 17 років існування дендропарку на відкритих ділянках парку (галявинах, луках, узліссях) з'явились нові насадження природного походження 3 малоцінних деревних і чагарникових видів. Унаслідок цього повністю перекрита видова панорама від центральної алеї до водойми та бесідки.

3. Доведено, що новоутворені насадження мають малодекоративний вигляд, вони змінюють співвідношення історичних ландшафтів, руйнують планувальну структуру та загальний вигляд парку.

4. Внаслідок проведення дослідження встановлено, що наявні паркові насадження мають задовільні лісотаксаційні показники та продуктивність, але їх санітарний стан потребує покращення, а саме проведення лісогосподарських, санітарно-оздоровчих і інших заходів.

5. Запропоновано збільшити видове різноманіття дендрофлори парку за рахунок перспективних інтродукованих видів, а саме Chaenomeles japonica Lindl., Berberis thunbergii DC., Lauras nobilis L., Abies concolor (Gord.) Hoops., Mahonia aquifolium (Pursh) Nutt. та інші.

6. Рекомендовано встановити у парку малі архітектурними форми, а саме вазони, лавки, вуличне освітлення, урни, інформаційні стенди.

\section{References}

1. Dzyba, A. A. (2012). Topiary art: methodical recommendations for conducting practical classes. Kyiv: TsP "Komprynt", 124 p. [In Ukrainian].

2. Field-Map. (2010). Programnoe obespechenie i oborudovanie. Katalog. 48 p. Retrieved from: https://www.fieldmap.cz/download/FM_catalogue_ru.pdf. [In Russian].

3. Lanovenko, O. H., \& Ostapishyna, O. O. (2013). Dictionary-reference book on ecology: Educational and methodical manual. Kherson: PP Vyshemyrskyi, V. S., 226 p. [In Ukrainian].

4. Nakaz № 226 vid 24.12.2001 (2001). Pro zatverdzhennia Instruktsii $z$ inventaryzatsii zelenykh nasadzhen $u$ naselenykh punktakh Ukrainy. Retrieved from: http://zakon3.rada.gov.ua/laws/show/z0182-02. [In Ukrainian].

5. Oleksiichenko, N. O., \& Hatalska, N. V. (2012). Parky-pamiatky sadovo-parkovoho mystetstva Tsentralnoprydniprovskoi vysochynnoi oblasti: monohrafiia, 1. Kyiv: TsP "Komprynt", 145 p. [In Ukrainian].

6. Serebryakov, I. G. (1962). Ecological morphology of plants. Life forms of angiosperms and conifers. Moscow: Vyisshaya shkola, 378 p. [In Russian].

7. The plant list. (2019). Retrieved from:http://www.theplantlist.org.

8. Udovychenko, V. V. (2017). Nature reserve fund of the territory of the Left Bank of Ukraine as a basis for the development of the ecological network of the region. Ukrainskyi heohrafichnyi zhurnal, 1, 38-47. Retrieved from: http://nbuv.gov.ua/UJRN/UGJ_2017_1_8. [In Ukrainian].

9. Zakon Ukrainy. (1992). Pro pryrodno-zapovidnyi fond Ukrainy. Vidomosti Verkhovnoi Rady Ukrainy (VVR), 34, st. 502. Retrieved from: https://zakon.rada.gov.ua/laws/show/2456-12\#Text. [In Ukrainian].

O. I. Lialin1, V. V. Bondarenko1, S. I. Musienko', O. M. Tarnopilska1, L. I. Tkach', A. V. Babenko²

${ }^{I}$ Ukrainian Research Institute of Forestry and Forest Melioration named after G. M. Vysotsky, Kharkiv, Ukraine ${ }^{2}$ O. M. Beketov National University of Urban Economy, Kharkiv, Ukraine

\title{
THE CURRENT STATE OF THE PLANTATIONS OF VOLODYMYRIVSKY ARBORETUM OF GUTYANSKE FORESTRY ENTERPRISE AND PROSPECTS OF ITS DEVELOPMENT
}

\begin{abstract}
The dendrological part of the forest fund, which is located in sq. 32 of the Volodymyrsky Arboretum of Gutyanske Forestry and is administratively located on the territory of Muraf Village Council of Krasnokutsky District of Kharkiv Region, at a distance of $12 \mathrm{~km}$ northeast of the village of Krasnokutsk. The subjects for the study were written and cartographic materials about the object of research, as well as the results of field surveys of the arboretum. The research was conducted by the method of sub-tree inventory in accordance with the instructions for the inventory of plantations. Field-Map technology was used in the research. According to existing information, the total area of Volodymyrsky Arboretum is about 7.0 hectares. After studying the historical and cartographic materials, as well as the study of the territory, we established the actual balance of the territory. The total area of the arboretum is 6.56 ha, and 4.83 ha (or $73.6 \%$ ) are covered with trees and shrubs, and 1.73 ha (or $26.4 \%$ ) are not covered and are used as roads (paths, roads) and as areas for walking and recreation. The predominant tree species in the Volodymyrsky Arboretum is Pinus sylvestris L. Its plantations of artificial origin of 50-60 year old with shrub undergrowth cover an area of 0.28 ha, and natural seed plants of 8-12 year old - 3.35 ha, which together is 3.63 ha, or $51 \%$ of the arboretum area. Spruce (Picea abies (L) Karst) occupies 0.28 ha, or $4.3 \%$ of the arboretum area and grows in the curtain N 18 alley. Alleys of larch (Japanese) (Larix kaempferi) (curtain N 19 ) is located on an area of 0.23 ha, or $3.5 \%$, and the alley of western thuja (Thuja occidentalis L.) (curtain N 20) - 0.12 ha. Common oak (Quercus robur L.) is represented by two curtains (N 7 and 21) and covers an area of 0.22 ha, or $3.4 \%$ of the arboretum area; red oak (Quercus rubra L.) (curtain N 11) - 0.12 ha. Other species occupy a small area or are represented by single specimens. As a result of research and analysis of the territory of the Volodymyrsky Arboretum, we can note that the created curtains of wood species have mainly preserved their contours. At the same time, during 17 years of the arboretum existence, new plantings of natural origin from low-value tree and shrub species have appeared in the open areas of the park (lawns, meadows, and outskirts).
\end{abstract}

Keywords: arboretum; dendrological part of the forest fund; species composition; condition assessment. 